\title{
Pathogenic Capacity of Botrytis cinerea on Leaves of Pyrus ma- morensis, an Endemic Tree of Mamora Forest in Morocco
}

\author{
Zineb Sellal, Jamila Dahmani, Rachid Benkirane, Amina Ouazzani Touhami, and Allal Douira* \\ Laboratoire de Botanique et Protection des Plantes, Département des Sciences de la Vie, Faculté des Sciences, \\ B. P. 133, Université Ibn Tofail, Kénitra, Morocco.
}

Received: June 28, 2012 / Accepted: September 15, 2012

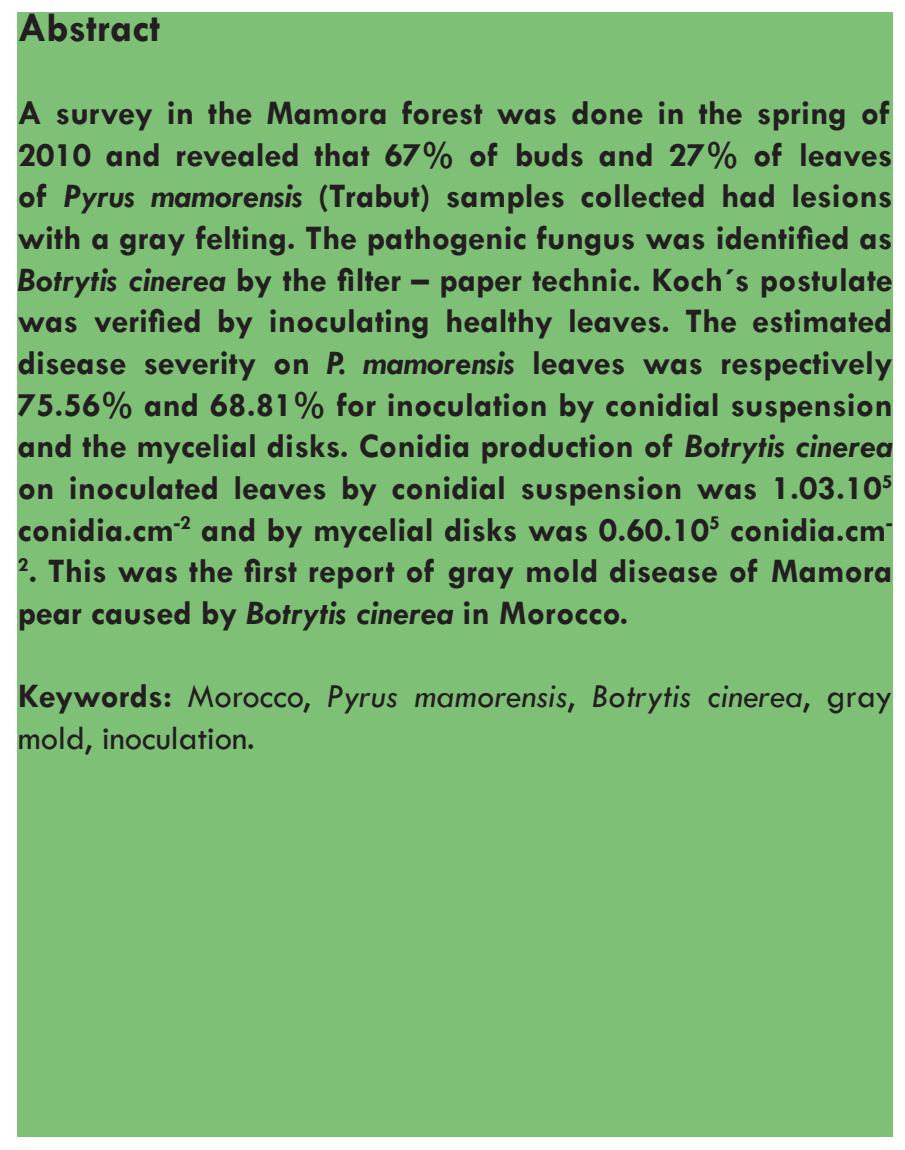

* Corresponding author: douiraallal@hotmail.com

\section{Introduction}

Mamora pear (Pyrus mamorensis, Trabut) is a perennial plant belonging to Rosaceae. Its abundant in Mamora forest (Morocco) is particular but does not form large stands. This species does not receive any conservation effort despite its endemism and rarity (Fennane et al., 1998). In addition, the reasons of the declining health of this tree over the long term and especially in periods of drought where stress by human activity, livestock grazing and attack by Pestalotia subcuticularis (Yamni et al., 2006). Other fungi were also isolated from leaves, flowers, fruits or trunk of this tree as Aspergillus niger, A. fumigatus, A. Versicolor, Alternaria alternata, Cladosporium herbarum, Drechslera australiensis, Mucor sp., Rhizopus stolonifer, Epiccocum nigrum, Trichoderma harzianum, Curvularia lunata, Hysterium pulicare, H. asymetricum, and Trematosphaeria pertusa (Sellal et al., 2012).

In the spring of 2010, the survey in the Mamora forest revealed that $67 \%$ of 100 buds and $27 \%$ of 100 leaves collected from eight trees of Pyrus mamorensis had lesions with a gray felting. Leaf blights were gray with brown contour (Fig. 1a). The other lesions were brown spots with a gray center (Fig. 1b). The buds were brown with a gray felting (Fig. 1c). This was the first time that these symptoms were observed on Pyrus mamorensis, endemic species in Morocco.

The objective of this work was to achieve isolation of the pathogenic fungus from the diseased leaves and buds of Pyrus mamorensis Trabut and to verify the Koch's postulate. 

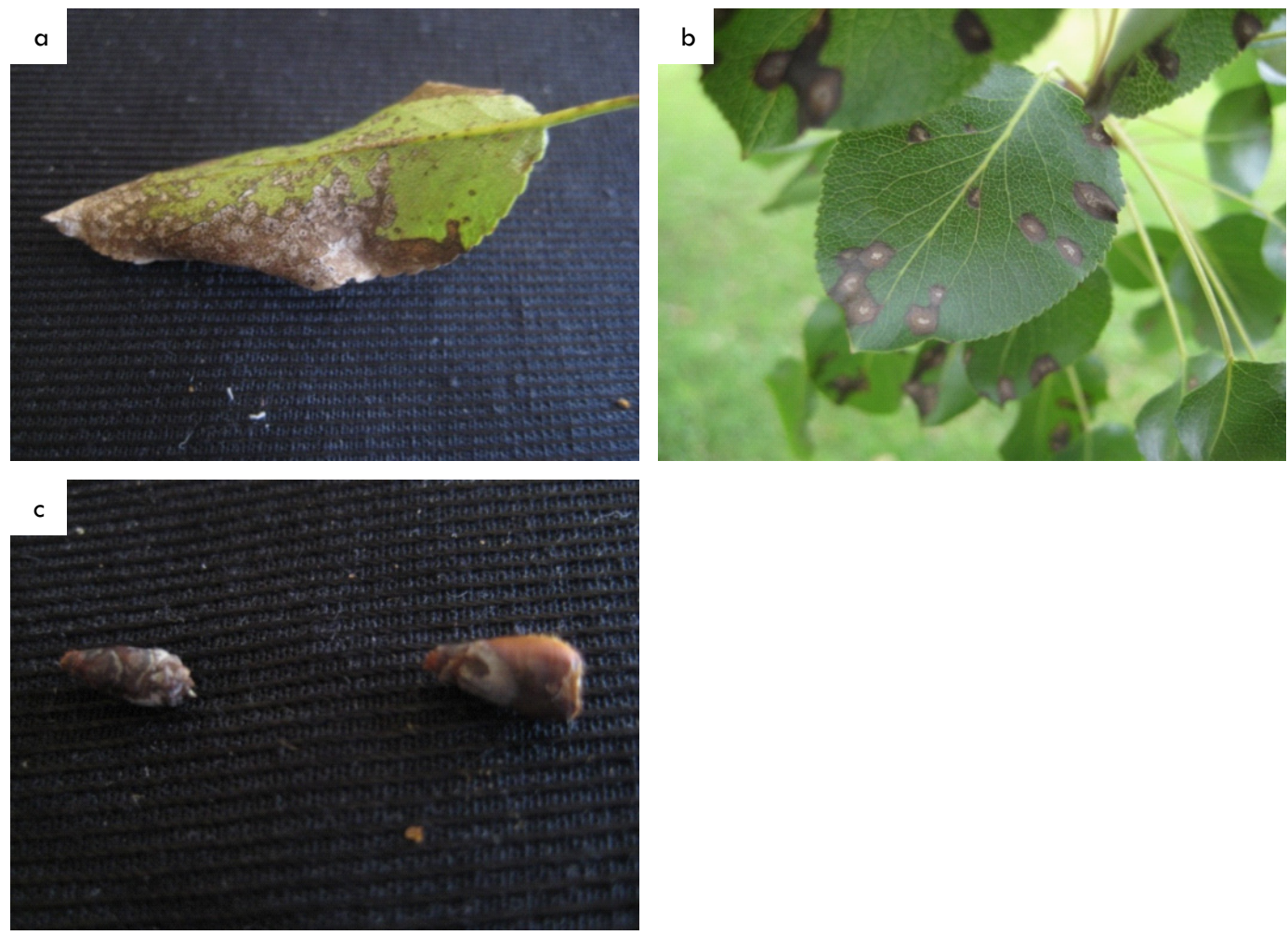

Fig. 1. Botrytis cinerea symptoms developed on leaves (a, b) and buds (c) of Pyrus mamorensis.

\section{Material and Methods}

Twenty leaves and ten buds showing lesions with a gray felting collected from eight trees of Pyrus mamorensis were cut into fragments, washed in tap water, disinfected with alcohol and placed in Petri dishes on filter paper moistened with sterile distilled water. After incubation at $22^{\circ} \mathrm{C}$ under continuous lighting for 2-3 days, leaves and buds fragments were examined using an optical microscope and the conidia emerging from the lesions were taken with a capillary tube and displayed on agar medium (15 g Agar-agar, distilled water $1000 \mathrm{ml}$ ). A single spores were placed on PSA medium (Potato Sucrose Agar: 200 $\mathrm{g}$ potato, $20 \mathrm{~g}$ sucrose, $15 \mathrm{~g}$ Agar-agar, distilled water 1000 $\mathrm{ml}$ ) and incubated in the dark for five days at $28^{\circ} \mathrm{C}$ (Benkirane, 1995). The developed colonies represented as a pure cultures, were retained and used for species determination.

Pathogenicity tests were realized by inoculating healthy leaves of Pyrus mamorensis using two technics. The surface of sixty leaves was disinfected with $5 \%$ sodium hypochlorite, washed with sterile distilled water and dried on a filter paper. Fifteen leaves were inoculated with mycelial disks of the fungus, the other fifteen by a conidial suspension adjusted to a final concentration of 105 conidia.ml- 1 with sterile distilled water containing $0.05 \%$ Tween 20 and $5 \%$ gelatin. Thirty leaves were used as a control, the half of them were inoculated with distilled water containing Tween 20 and gelatine and the other half with medium plugs. Every bunch of five leaves was placed in 120-mm
Petri dish containing small glass beads and sterile distilled water. Inoculated leaves were incubated at $28 \pm 1{ }^{\circ} \mathrm{C}$ under black plastic sheeting that was removed after $24 \mathrm{hrs}$.

The disease severity was scored after 7 days of inoculation using the scale of Stover modified by Gauhl et al., (1995).

\begin{tabular}{cccccccc}
\hline Class & $\mathbf{1}$ & $\mathbf{2}$ & $\mathbf{3}$ & $\mathbf{4}$ & $\mathbf{5}$ & $\mathbf{6}$ & $\mathbf{7}$ \\
\hline \% Diseased & $-0,5 \%$ of the & $0,6 \grave{a}$ & $6 \grave{a}$ & $16 \grave{a}$ & $31 \grave{a}$ & $51 \grave{a}$ & $81 \grave{a}$ \\
leaf area & $\begin{array}{c}\text { limbus with } \\
\text { symptoms }\end{array}$ & $5 \%$ & $15 \%$ & $30 \%$ & $50 \%$ & $80 \%$ & $100 \%$ \\
\hline
\end{tabular}

The severity index (IS) of disease was calculated using the formula:

$$
\mathrm{IS}=\left(\sum \mathrm{nb} /(\mathrm{N}-1) \times \mathrm{T}\right) \times 100
$$

$\mathrm{n}=$ Number of leaves for each degree of the scale

$b=$ Degree of the scale

$\mathrm{N}=$ Number of the degrees used in the scale

$\mathrm{T}=$ Total number of the scored leaves

The conidia production (conidia $\mathrm{cm}^{-2}$ ) of Botrytis cinerea on the inoculated Mamora pear leaves was estimated according to the technic of Hill and Nelson (1983). Ten days after inoculation, the leaves those had shown lesions were cut into pieces of $1 \mathrm{~cm}^{2}$ and placed in $90 \mathrm{~mm}$ Petri dishes on three filter paper discs moistened with sterile distilled water. The dishes were in- 
cubated for 48 hours under continuous fluorescent lighting. Then each fragment was placed in a test tube containing $1 \mathrm{ml}$ of sterile distilled water and agitated by a vortex mixer for $2 \mathrm{~min}$. The conidia of the pathogen were counted using a Malassez slide under an optical microscope at magnification $\times 100$ with 10 counting of each sample.

\section{Results and Discussion}

On PSA, the growing colonies of the isolated fungus were white at first, gray as it ages and whitish gray in reverse (Fig. $2 \mathrm{a})$. The mycelium was very large and dense, $12 \mu \mathrm{m}$ of wide, cylindrical, often banded, especially when cultures are older. It appeared light brown to olive. The conidiophores were clear colored and shiny. Their back always branched (Fig. 2b) and supported small sterigmata. The conidia were ellipsoidal or obovoid, with slightly protuberant hilum colorless to pale brown 7-15 x 5-9 $\mu \mathrm{m}$ (Fig. 2c) and abundant sclerotia developed as the fungus culture ages. Based on the morphological description Ellis (1971), the fungus was identified as Botrytis cinerea Pers. 1794.

Botrytis species were important pathogens of nursery plants, vegetables, ornamental, field and orchard crops, stored and transported agricultural products (Elad et al., 2007).

The Botrytis cinerea Pers. ex Fr. caused gray mold disease in a wide variety of hosts (Coley-Smith et al., 1980; Elad et al., 2004), and was a serious economic problem in crops such as table grapes, vines, strawberries, raspberries, lettuce, cucum- bers, broad beans, tomatoes, beans, flowers, and forest plants produced in containers (Elad et al., 2004). Gray mold was an important sanitary problem in Pinus radiata D. Don and Eucalyptus globulus Labill. in Chilean forest nurseries (Butin and Peredo, 1986). Botrytis sp. and B. cinerea were also isolated from the young diseased plants of Cedrus atlantica (Endl.) Manetti ex Carriere respectively in Morocco (Bakry et Abourouh, 1992) and in France (Abourouh et Morelet, 1999). B. cinerea seemed to prefer senescent leaves but were also found in other stages in Quercus rotundifolia Lam. in a holm oak forest (High Atlas, Morocco) (Sadaka and Ponge, 2003).

Two days after inoculation of leaves of Pyrus mamorensis with conidial suspension, the first symptoms of Botrytis cinerea appeared at the limbus and then covered the entire leaf surface. The lesions were brown to black (Fig. 3b). The second type of lesions were black that appeared first at the tips then grew and covered the leaf surface (Fig. 3c).The lesions appeared also on the petioles.

The inoculated leaves with mycelial disks showed brown lesions, grayish to blackish in the disk and then cover leaf surface with blackening of the petiole (Fig. $4 \mathrm{~b}$ and c). Seven days after inoculation, the estimated disease severity on leaves of P. mamorensis was $75.56 \%$ and $68.81 \%$ for inoculation by conidial suspension and the mycelial disks. No disease was observed on the control leaves (Fig. 3a and Fig. 4a).

Ten days after inoculation, Botrytis cinerea produced conidia abundantly on leaves of P. mamorensis inoculated both by conidial suspension $\left(1.03 .10^{5}\right.$ conidia. $\left.\mathrm{cm}^{-2}\right)$ and the mycelial disks
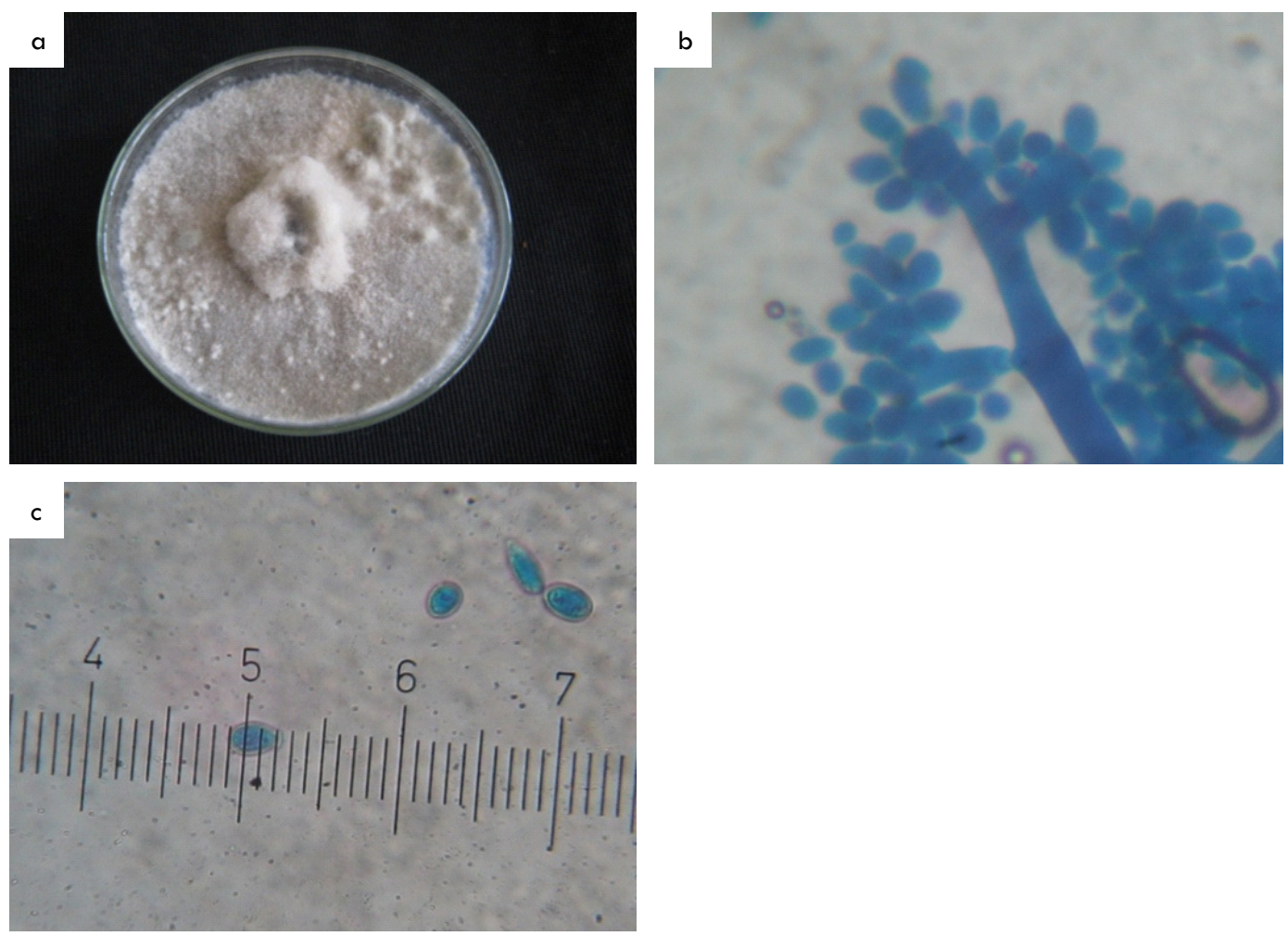

Fig. 2. Botrytis cinerea on PDA (a), conidiophores (b) and conidia (c) on cotton blue $(\times 400)$. 

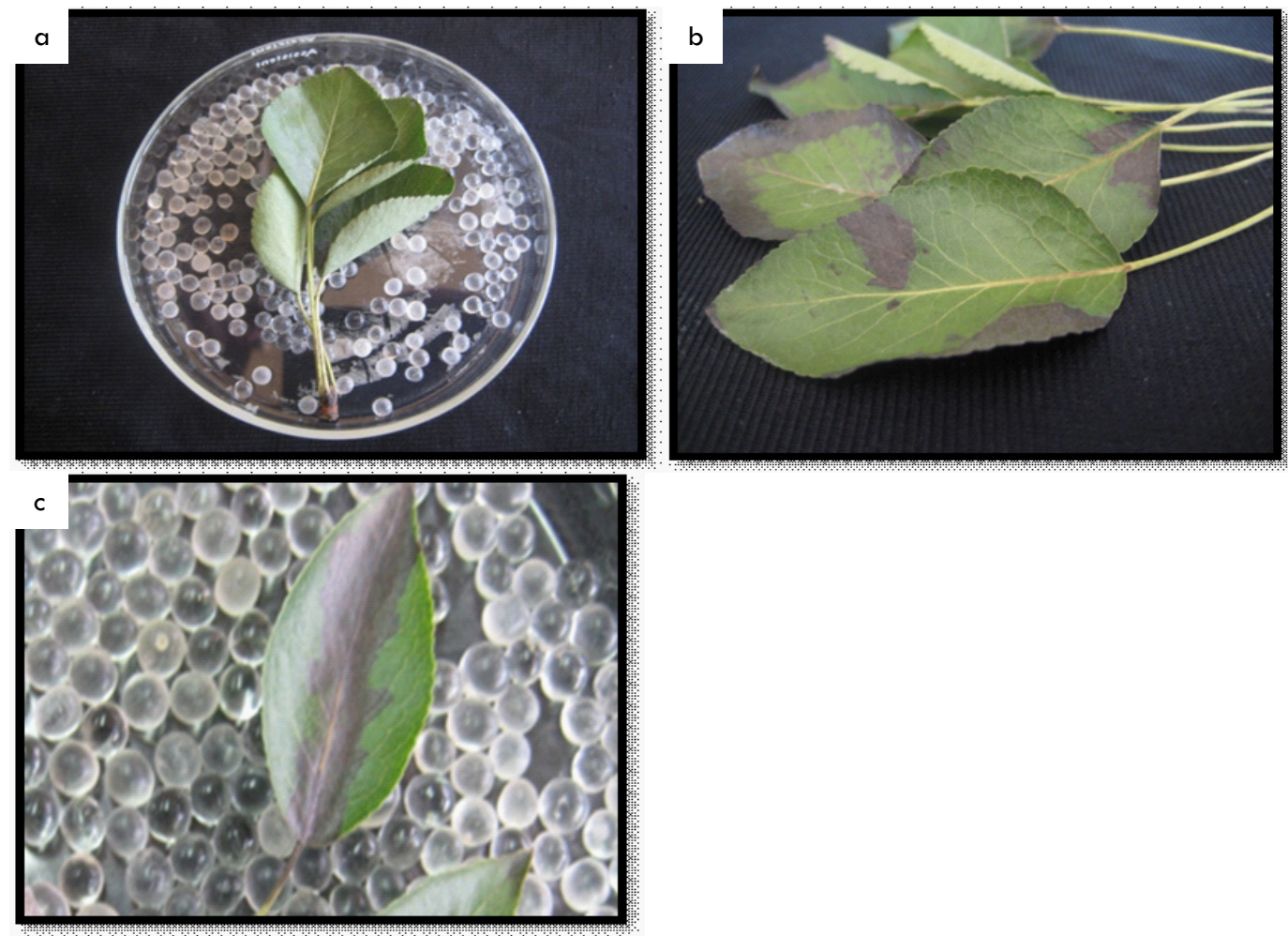

Fig. 3. Symptoms caused by B. cinerea on leaves of Pyrus mamorensis inoculated with conidial suspension (b, c), control (a).

(0.60.10 $0^{5}$ conidia. $\left.\mathrm{cm}^{-} 2\right)$.

The pathogen was a common fungus that damaged flowers, leaves, stems, fruit and other parts of many plants (Ellis, 1971; Elad and Shteinberg cited by O'Neill et al., 1997). The fungus exists in different habitats as mycelia, micro- and macroconidia, chlamydospores, sclerotia, apothecia and ascospores and these are dispersed by diverses means (Jarvis, 1980). If it is to infect, the fungus must conquer space (Zadocs and Scein, 1979) that is to move from the primary source and land on susceptible tissue. Each part of the fungus thallus can serve as a dispersal unit. These propagules are dispersed by wind, rain and insect.

Botrytis cinerea was observed causing gray mold in Pyrus communis (Sommer et al., 1985; Shiva, 1989; Crous et al., 2000), P. serotina (Cho and Shin, 2004) , P. serotina var. culta and P. betulifolia (Kobayashi, 2007).

However, to our knowledge, this was the first report of gray mold disease of Pyrus mamorensis caused by Botrytis cinerea in Morocco. The pathogen was a real threat to this tree already weak.

\section{References}

Abourouh $M$ and $M$ Morelet (1999) Les champignons parasites du Cèdre de l'Atlas en Afrique du nord et en France. Forêt méditerranéenne t. XX, $4:$ 198-202.

Bakry $M$ and $M$ Abourouh (1992) La fonte des semis - premiers résultats sur les pertes en pépinières forestières. Annales Recherche Forestière Maroc T. $26: 113-126$.
Benkirane R (1995) Contribution à l'étude des maladies du riz au Maroc. Cas de la pyriculariose due à Pyricularia oryzae .Thèse de troisième cycle. Université Ibn Tofail, Faculté des sciences, Kénitra, Maroc, 189p.

Butin $\mathrm{H}$ and YH Peredo (1986) Hongos parásitos en coníferas de América del Sur con especial referencia a Chile. Bibliotheca Mycologica. Ed. Cramer, Berlín, Alemania, 100 p.

Cho WD and HD Shin (2004) List of plant diseases in Korea, $4^{\text {th }}$ edition, Korean society of Plant Pathology, $779 \mathrm{pp}$.

Coley-Smith J, K Verhoeff, and W Jarvis (1980) The biology of Botrytis. Academic Press, London, UK, 318 p.

Crous PW, AJL Phillips, and AP Baxter AP (2000) Phytopathogenic Fungi from South Africa, University of Stellenbosch, Department of plant Pathology Press, $358 \mathrm{pp}$.

Elad Y, B Williamson, P Tudzynski, and N Delen (2004) Botrytis: Biology, pathology and control. Kluwer Academic Press, Dordrecht, The Netherlands, $403 \mathrm{p}$.

Elad Y, B Williamson, P Tudzynski, and N Delen (2007) Botrytis spp. and diseases they cause in agricultural systems- an introduction. pp. 1-24. In: Botrytis: Biology, pathology and control, (Elad Y, Williamson B, Tudzynski P., Delen N. ed.), Springer, 403 pp.

Ellis MB (1971) Dematiaceous Hyphomycetes, Commonwealth Mycological Institute, Kew, England, 608 pp.

Fennane M, M Ibn Tattou, FM Raimondo, and B Valdés (1998) Catalogue des plantes vasculaires rares, menacées ou endémiques du Maroc, (F.M. Raimondo, B. Valdés, ed.), Published under the auspices of OPTIMA by the Herbarium Mediterraneum Panormitanum 'Boc conea', Palermo, Italy, 8, 243 pp.

Gauhl F, C Pasberg-Gauhl, D Vuylsteke, and R Ortiz (1995) Multilocational evaluation of black Sigatoka resistance in banana and plantain. IITA Research Guide 47. 2nd edition. Training Program, 
International Institute of Tropical Agriculture (IITA), Ibadan, Nigeria. $59 \mathrm{pp}$.

Jarvis WR (1980) Epidemiology. In : Coley-Smith JR, Verhoeff K and Jarvis WR (eds). The Biology of Botrytis (pp. 219-250) Academic Press, London, UK.

Kobayashi T (2007) Index of fungi inhabiting woody plants in Japan. Host, Distribution and Literature, Zenkoku-Noson- Kyoiku Kyokai Publishing Co., Ltd., 1227 pp.

O'Neill TM, D Shteinberg, and Y Elad (1997) Effect of some host and microclimate factors on infection of tomato stems by Botrytis cinerea. Plant Disease 81 (1) : 36-40

Sadaka N and JF Ponge (2003) Fungal colonization of phyllosphere and litter of Quercus rotundifolia Lam. in a holm oak forest (High Atlas, Morocco) Biology and Fertility of Soils 39: 30-36.
Sellal Z, J Dahmani, R Benkirane, A Ouazzani Touhami, and A Douira (2012) Etude de la mycoflore associée à Pyrus mamorensis Trabut, arbre endémique de la forêt de la Mamora (Maroc). Revue Marocaine de Protection des Plantes $3:$ 71-86.

Shivas RG (1989) Fungal and bacterial diseases of plants in Western Australia. Journal of the Royal Society Western Australia 72: 1-62.

Sommer NF, JR Buchanan, RJ Fortlage, and BE Bearden (1985) Relation of floral infection to Botrytis blossom-end rot of pears in storage. Plant Disease 69: 340-343.

Yamni K, N Dohou, A Outkoumit, A Ouazzani Touhami, and A Douira (2006) First report of Pestalotia subcuticularis on Pyrus mamoremsis in Morocco. Phytopathologia Mediterranea 45: 40-42.

Zadocs JC and RD Schein (1979) Epidemiolgy and Plant Disease Managment. Oxford University Press Inc., New York, USA, 427p. 